\title{
Implementation of pain control program in a traumatology and orthopedics hospital. Case report
}

\author{
Implementação de um programa de controle da dor em hospital de traumatologia e ortopedia. \\ Relato de caso
}

Marcio Curi Rondinelli ${ }^{1}$, Juliane de Macedo Antunes ${ }^{2}$, Waleska de Castro Sampaio', Jamila Ferreira Miranda dos Santos ${ }^{2}$

DOI 10.5935/1806-0013.20160032

\section{ABSTRACT}

BACKGROUND AND OBJECTIVES: Pain is one of the most frequent clinical complaint in daily, ambulatory and hospital practice. Regardless of its cause, it remains undervalued and, as a consequence, without adequate management, resulting in poor control, thus impairing a physical and social rehabilitation proposal. This study aimed at presenting a pain control program and at spreading the real advantages of its implementation.

CASE REPORT: This is a descriptive study with experience report of a national reference orthopedic surgical hospital exclusively assisting Single Health System patients.

CONCLUSION: This experience and its results encourage the maintenance of the Pain Control Policy and contribute to reference to other health institutions the benefits of implementing similar programs and policies.

Keywords: Fifth vital sign, Indicators, Pain control program.

\section{RESUMO}

JUSTIFICATIVA E OBJETIVOS: A dor é uma das mais frequentes queixas clínicas na prática diária, ambulatorial e hospitalar. Independentemente da sua causa, permanece subvalorizada e, consequentemente, sem tratamento adequado, resultando em insucessos no seu controle, prejudicando uma proposta de reabilitação física e social. O objetivo deste estudo foi apresentar o programa de controle da dor e divulgar as reais vantagens de sua implementação.

1. Clínica da Dor do Instituto Nacional de Traumatologia e Ortopedia, Departamento Médico, Janeiro, RJ, Brasil.

2. Clínica da Dor do Instituto Nacional de Traumatologia e Ortopedia, Departamento de Enfermagem, Rio de Janeiro, RJ, Brasil.

Submitted in September 02, 2015.

Accepted for publication in April 20, 2016.

Conflict of interests: none - Sponsoring sources: none.

Correspondence to:

Avenida Brasil 500

20940-070 Rio de Janeiro, RJ, Brasil.

E-mail: rondinelli@openlink.com.br

( ) Sociedade Brasileira para o Estudo da Dor
RELATO DO CASO: Trata-se de um estudo descritivo com relato de experiência, em um hospital cirúrgico ortopédico, de referência nacional que atende exclusivamente pacientes do sistema único de saúde.

CONCLUSÃO: Essa experiência e seus resultados incentivam a manutenção da Política de Controle da Dor e contribuem para referenciar a outras instituiçóes de saúde os benefícios da implementação de programas e políticas semelhantes.

Descritores: Indicadores, Programa de controle da dor, Quinto sinal vital.

\section{INTRODUCTION}

Pain has always been part of men's lives and is a warning sign. Its chronicity negatively impacts human physical and mental health. Currently, it is estimated that patients with postoperative acute pain, or chronic pain, cost billions of reals to the country in working days lost, legal compensations, insurance and therapies $^{1-3}$.

In practice, it is observed that notwithstanding major advances in pain management and therapy, it is still underappreciated and, as a consequence, it is not timely treated resulting in poor control.

Pain worsens disabling physical and emotional disorders, regardless if the baseline disease is known or not ${ }^{4}$. Attention and prompt assistance to painful patients are critical for the health institution, and that is why it is considered the fifth vital sign, together with temperature, heart rate, respiratory rate and blood pressure.

Pain clinical characteristic helps directing the etiology. Nociceptive pain is in general due to diffuse tissue injury, with punctual pain manifestations, pressing or in tension. Neuropathic pain, on the other hand, implies nervous fibers involvement and in general has flashing or burning symptoms, in addition to diffuse and imprecise location. It is important to consider that mixed symptoms are frequent, making difficult therapeutic intervention ${ }^{4}$.

The Instituto Nacional de Traumatologia e Ortopedia Jamil Haddad (INTO) has implemented a Pain Evaluation and Control Program involving all institution's health professionals and considering its management a stage as important as curing the disease. Its benefits are evident because pain control decreases joint disorders and muscle hypotrophy, improves cardiorespiratory dynamics, prevents thromboembolic 
phenomena and autonomic disorders, and improves anxiety and depression. In addition to bringing comfort to patients and to the health team, the program provides early rehabilitation and hospital discharge. For the institution, it makes beds turnover dynamic and decreases legal issues.

This study aimed at presenting the pain control program adopted by INTO and at spreading the real advantages of its implementation, in addition to benefits to patients, health team and the institution.

\section{EXPERIENCE REPORT}

This is a descriptive study on an experience report, as from the year 2006, where we tried to describe the road followed by the multiprofessional team to implement the pain control program in a national reference surgical orthopedic hospital exclusively assisting patients of the single health system (SUS). INTO is today the single Brazilian hospital and one of the 18 international hospitals integrating the International Society of Orthopedic Centers (ISOC), which congregates the best existing orthopedic hospitals. It has international certification by the Joint Commission International (JCI/CBA) which has been renewed three times since 2006 .

INTO has 21 operating rooms, among them one for emergencies and two with satellite live transmission equipment, in addition to 255 hospitalization beds and 48 intensive care and postoperative beds.

\section{Program description}

This is a pain control program with analgesic protocol and routines agreed with other departments of the institution. It consists of pain recording as the fifth vital sign using validated scales for pain evaluation, and indicators helping quality surveillance. It also encompasses ongoing education strategies for INTO professionals.

The National Policy of Ongoing Health Education, introduced by the Ministry of Health by means of Ordinance 198, from February 2004, allows for the identification of qualification and development needs of healthcare workers and the building of strategies qualifying health attention and management aiming at generating a positive impact on individual and collective health ${ }^{5,6}$.

\section{Pain intensity scales used by INTO}

Pain intensity evaluation and recording should include not only oriented individuals, but also neonates, cognitive deficit or sedated patients. So, four scales were used according to patients' specificities, as follows:

\section{Visual analog scale (VAS)}

Used for oriented and literate patients, with scores from zero $=$ no pain to $4=$ severe pain, associated to faces. This scale was validated by Goddard ${ }^{7}$.

CRIES Scale (Crying, Requires oxygen for saturation above $95 \%$, increased vital signs, Expression, Sleepless)
Used with children up to one year of age ${ }^{8}$, with scores from zero to 10 , according to crying, oxygen requirement, increased heart rate and blood pressure, face expression and sleep in the last hour. Although still being validated, this scale was chosen for better adapting to the profile of patients between zero and one year of age, submitted to surgeries due to congenital abnormalities and postpartum brachial injuries.

\section{CHEOPS Scale (Children's Hospital of Eastern Ontario Pain Scale) \\ Scale validated by McGrath ${ }^{9}$ and used with children from one to seven years of age with scores from 4 to 13 according to cri- teria: crying, face and verbal expression, trunk movement, pos- ture with regard to surgical wound and lower limbs movement.}

\section{CPOT scale (Critical Care Pain Observation)}

Scale used with patients with cognitive deficit or sedated, by means of scores from zero to 10 , according to criteria: face expression, body movement, muscle tension, compliance with ventilator, or vocalization and blood pressure and/or heart rate ${ }^{10}$.

\section{Indicators and postoperative results}

Quality indicators are used as tools to help quality surveillance and the identification of opportunities for improvement. Since 2011, pain relief area team (ARDOR) manages five indicators as quality tools:

\section{- Postoperative pain score record}

The objective is to monitor adequate pain intensity recording, allowing for prompt therapeutic intervention.

\section{- Use of analgesic protocol instituted by INTO}

To evaluate whether the analgesic protocol is being adequately used and whether its use positively impacts pain control.

\section{- Pain revaluation record}

When pain intensity is identified as equal to or above moderate, there shall be intervention (pharmacological or not), and pain shall be evaluated within 45 to 60 minutes. This indicator shows whether revaluation is being performed.

\section{- Pain location and characteristic record}

Indicator giving attention to real pain location and symptoms which may help identifying predominantly neuropathic or nociceptive pathophysiology, thus modifying the analgesic protocol.

\section{- Pain evaluation checking}

This compares the similarity of pain evaluation between clinical pain team and hospital admission staff on duty.

It evaluates the similarity of pain recording between nursing team on duty and pain clinic nursing team.

The first four indicators are evaluated every four months by means of randomly chosen medical charts. A number (" $n$ ") was calculated, corresponding to surgeries performed in the elected month, by two collaborators who separately evaluate the same medical charts aiming at giving reliability to the result. " $\mathrm{n}$ " calculation is obtained by means of a formula from the www.calculoamostral.vai.lá.com website ${ }^{11}$ according to orientation of the Brazilian Accreditation Consortium. For 
the fifth indicator, data are annually collected by means of patient's evaluation since it is the evaluation similarity indicator, where evaluations of pain clinic team and of hospital admission nursing team are compared.

Results of the four indicators evaluated by INTO are detailed below. Important to mention that the term "NONCONFORMITY", recommended by the hospital accreditation manual ${ }^{12}$ - CBA, and which quantifies such indicators, is referred to what has to be improved. Low scores of collected indicators prove the satisfactory result obtained by the institution's pain record and control team.

The same manual also mentions the importance of agreeing targets to obtain parameters to help monitoring such indicators.

Targets are intended performance levels for a certain period of time ${ }^{13}$. Although target being a number or a precise objective, its theoretical definition is totally subjective, because it is totally related to the point one intends to reach. So, target has to be a balance between executable and conquerable. Targets agreed by the pain team were based on clinical practice since 1999 and are annually revaluated.

\section{Postoperative pain score record (Table 1)}

- Nonconformity index on postoperative pain records

- Indicator target: $5.00 \%$

- Indicator formula:

Number of nonconforming pain evaluation records $\mathrm{x} 100$

Total number of evaluated patients.

There were $3.15 \%$ above established target. However, nonconformity of pain records is declining. So, to reach the established target of just $5 \%$ on nonconformity of pain recording in the vital signs chart, it is necessary, in addition to sensitizing, to qualify the health team for action. For better adhesion and sensitization of professionals the qualification on service was adopted ${ }^{6,14}$.

\section{Use of analgesic protocol instituted by INTO (Table 2)}

- Nonconformity index of analgesic protocol

- Indicator target: $5.00 \%$

- Indicator formula:

Number of protocols not followed with painful patients $x 100$ Total number of evaluated patients

In 2014, indicator was $2.36 \%$ above target, however, as it could be observed, these figures are considerably decreasing and it is worth stressing that as from 2013, the presence of physicians on training courses of the pain clinic has been required.

\section{Pain revaluation record (Table 3)}

- Nonconformity index of pain revaluation records

- Indicator target: $10.00 \%$

- Indicator formula:

Number of nonconformities in pain revaluation records $\mathrm{x}$ 100

Total number of evaluated patients.

There has been real compliance with established target. But the team studies the possibility of decreasing such target for being a relevant pain control indicator.

\section{Pain location and characteristic record (Table 4)}

- Nonconformity index of pain location and characteristic record

- Indicator target: $10.00 \%$

- Indicator formula:

Number of nonconformities in pain location and characteristic record $\times 100$

Total number of evaluated patients

Table 1. Pain record

\begin{tabular}{lcccc}
\hline Indicator & \% of nonconformities & \% of nonconformities & \% of nonconformities & \% of nonconformities \\
& 2011 & 2012 & 2013 & 2014 \\
\hline $\begin{array}{l}\text { Nonconformities on } \\
\begin{array}{l}\text { postoperative pain } \\
\text { records }\end{array}\end{array}$ & 4.42 & 15.02 & 10.38 & 8.15 \\
\hline
\end{tabular}

Table 2. Use of analgesic protocol

\begin{tabular}{lcccc}
\hline Indicator & $\begin{array}{c}\text { \% of nonconformities } \\
\text { 2011 }\end{array}$ & $\begin{array}{c}\text { \% of nonconformities } \\
2012\end{array}$ & $\begin{array}{c}\text { \% of nonconformities } \\
2013\end{array}$ & $\begin{array}{c}\text { \% of nonconformities } \\
2014\end{array}$ \\
\hline $\begin{array}{l}\text { Nonconformity of } \\
\text { analgesic protocol }\end{array}$ & 6.29 & 19.03 & 11.23 & 7.36 \\
\hline
\end{tabular}

Table 3. Pain revaluation

\begin{tabular}{lcccc}
\hline Indicator & \% of nonconformities & \% of nonconformities & \% of nonconformities & \% of nonconformities \\
& 2011 & 2012 & 2013 & 2014 \\
\hline $\begin{array}{l}\text { Nonconformity in pain } \\
\text { revaluation records }\end{array}$ & 9.9 & 4.05 & 7.36 & 5.69 \\
\hline
\end{tabular}


Table 4. Location and characteristic record

\begin{tabular}{|c|c|c|c|c|}
\hline Indicator & & & \multicolumn{2}{|c|}{ \% of nonconformities 2014} \\
\hline Nonconformity of pain & $\mathrm{n}$ and characteristic rec & & \multicolumn{2}{|r|}{3.69} \\
\hline Indicator & $\begin{array}{c}\% \text { of nonconformities } \\
2011\end{array}$ & $\begin{array}{l}\text { \% of nonconformities } \\
2012\end{array}$ & $\begin{array}{l}\text { \% of nonconformities } \\
2013\end{array}$ & $\begin{array}{c}\text { \% of nonconformities } \\
2014\end{array}$ \\
\hline $\begin{array}{l}\text { Non-similarity of pain } \\
\text { evaluation }\end{array}$ & 1.65 & 28.77 & 9.70 & 6.31 \\
\hline
\end{tabular}

These indicators started to be used in 2013 and were introduced in the official chart of monitored indicators in 2014, being maintained within established target.

\author{
Similarity of pain evaluation by INTO pain clinic team \\ and hospital admission team on duty (Table 5) \\ - Non-similarity index of pain evaluation \\ - Indicator target: $10.00 \%$ \\ - Indicator formula: \\ Number of evaluation similarity nonconformities x 100 \\ Total number of evaluated patients.
}

\section{DISCUSSION}

Results are within established targets, except for 2012, because INTO has started its activities in a new structure with a physical plant much better than previous one, increasing the number of medical assistances and making difficult the adequate evaluation.

This transition process, added to the acquisition of new professionals and changes in some working processes has led to increased nonconformity indices, as shown by tables above. However, these indices have progressively decreased along the years due to continuous pain team actions.

Ongoing assistance quality improvement is a dynamic and exhaustive process aiming at continuously identifying factors intervening with working processes. So, indicators, as quality surveillance tools and for the analysis of improvement opportunities, should be used to understand assistance performance and provide fast decision making to prevent the installation of the problem ${ }^{13,15,16}$.

For all targets to be met, ongoing education should be used as resource, which has to be understood both as teaching-learning practice and health education policy. As from this political-pedagogic challenge, ongoing health education was approved by the XII National Conference on Health and by the National Health Council (CNS) as specific policy interesting the national health system, which can be proven by Resolution CNS 353/2003 and Ordinance MS/GM 198/2004. So, ongoing health education has become a SUS strategy to qualify and develop healthcare workers 5 . Ongoing health education is the act of analyzing daily work and practices and qualification-attention-management-participation articulations. It is not a didactic-pedagogic process, it is a political-pedagogic process to change daily health service activities and to place professional routine in live interac- tion (in partnership with users). In this sense in Brazil, the concept of qualification quadrangle is based on education, which associates teaching and repercussions on work, health system and social participation ${ }^{6,14,17}$.

\section{CONCLUSION}

It is extremely important, for pain control, the use of indicators as management tools and the identification of improvement opportunities. With them, it has been possible to perform a real evaluation of the efficacy of this control in the institution, of the adhesion of health professionals to the subject and to direct improvement actions.

Ongoing education, by means of lectures, clinical meetings, scientific journeys and service discussions sensitizes and qualifies health area professionals aiming at the importance of adequate pain management.

\section{REFERENCES}

1. Mendes EV. As redes de atençáo à saúde. Brasília: Organizaçáo Pan-Americana da Saúde; 2011.30p.

2. Roenn JH, Paice JA, Preodor ME. Atual Diagnóstico e Tratamento da Dor. Rio de Janeiro: McGraw-Hill Interamericana do Brasil; 2008. 8p.

3. Organizaçāo Mundial da Saúde, Relatório Mundial da Saúde. Saúde mental: nova concepçấo, nova esperança. $1^{\text {a }}$ ed. Lisboa: Abril; 2002. 36p.

4. Treed RD, Jensen TS, Campbell JN, Cruccu G, Dostrovsky JO, Griffin JW, et al Neuropathic pain: redefinition and a grading system for clinical and research purposes. Neurology. 2008;70(18):1630-5.

5. BRASIL, Ministério da Saúde. Portaria GM/ MS n0 198, de 13 de fevereiro de 2004 Institui a Política Nacional de Educaçáo Permanente em Saúde. Diário oficial da Uniấo, Brasília, DF, 2004. Seção 1.

6. Ceccim RB. Educação permanente em saúde: desafio ambicioso e necessário. Interface. 2005;9(16):161-78.

7. Goddard JM, Pickup SE. Postoperative pain in children. Combining audit and a clinical nurse specialist to improve management. Anaesthesia. 1996:51(6):588-90.

8. Silva TP, Silva LJ. Escalas de avaliação da dor utilizadas nos recém-nascidos: revisão sistemática. Acta Med Port. 2010:23:437-54.

9. McGrath PA. An assessment of children's pain: a review of behavioral, physiological and direct scaling techniques. Pain. 1987;31(2):147-76.

10. Gélinas C, Fillion L, Puntillo KA, Viens C, Fortier M. Validation of the critical-care pain observation tool in adult patients. Am J Crit Care, 2006;15(4):420-7.

11. Santos GE. Cálculo amostral: calculadora on-line. Disponível em: <http://www.calculoamostral.vai.la>. Acesso em: 2/03/2015

12. JCI Accreditation Standards for Hospitals, $5^{\mathrm{a}} \mathrm{ed}$. Junho; 2014.

13. Pavani Jr O, Sucucuglia R. Mapeamento e Gestáo por Processos - BPM. Gestấo orientada a entrega por meio de objetos. Sáo Paulo: M. Books do Brasil; 2011.

14. Jarrett A, Church T, Fancher-Gonzales K, Shackelford J, Lofton A. Nurses' knowledge and attitudes about pain in hospitalized patients. Clin Nurse Spec. 2013;27(2)81-7.

15. Leăo ER, Silva CP, Alvarenga DC, Frota SH. Qualidade em Saúde e indicadores como ferramenta de gestâo. Yendis; 2008.

16. Ferreira DP. Indicadores de Saúde: Construçâo e uso. In: Cianciarullo TI, Corneta VK. Saúde, desenvolvimento: um desafio para os gestores do Terceiro Milênio. São Paulo: Ícone; 2000. 259-70p.

17. Bressan FR, Alves Neto O, Nóbrega MS, Tribbis Júnior N. Estratégia para a implementação de um serviço de tratamento da dor no hospital das clínicas da universidade federal de Goiás. Rev Dor. 2010;11(1):45-9. 